The Social Sciences 7 (2): 246-251, 2012

ISSN: $1818-5800$

(C) Medwell Journals, 2012

\title{
Niger Delta University and the Socio-Economic Life of Amassoma
}

\author{
Audu Nathan Pelesai \\ Department of Curriculum/Instruction, \\ Niger Delta University, Wilberforce Island, Bayelsa State, Nigeria
}

\begin{abstract}
The thrust of this study is to evaluate the impact of the establishment of Niger Delta University, Wilberforce island, Bayelsa state on the socio-economic life of Amassoma city with emphasis on the growth in population of the area in relationship to the availability of basic social amenities. To achieve this objective, researchers employed descriptive statistics in analysing the primary data collected. The findings reveals that there is insufficiency or neglect or total absence of basic necessities and this have put excessive pressure on these needs which has resulted in galloping inflation, thus leading to adverse socio-economic effects of the inhabitants of Amassoma and its environs. The study also reveals that the cost of land has increased 10-fold while buildings sprang up sporadically and haphazardly. Rent is exorbitant and the demand for basic infrastructure is on the increase but they are hardly found or totally absent in Amasoma. Crime has become the order of the day as Amassoma and its environs is gradually becoming a nightmare to the inhabitants and visitors alike. The study therefore, recommend that the rural, local and state government should intervene immediately to put an order in the development of the area in the provision of houses and other social amenities including crime prevention while the university authorities should come up with a plan for more student hostels on campus so that the university remains a place to be as the highest citadel of learning.
\end{abstract}

Key words: Socio-economic, university, house, population, necessity, students

\section{INTRODUCTION}

Amassoma is the headquarters' of Ogboin clan as well as Ogboin-North Rural Development Authority in the Southern-Ijaw local government area of Bayelsa state and the host community to the temporary site of Niger Delta University (NDU), Wilberforce island, Bayelsa state. NDU was established in the year, 2000 with its temporary site located at former Government Secondary School, Amassoma and since then, the university has witnessed a tremendous and steady growth rate in students' enrolment and staff population. The same applies to petty traders and businessmen, etc., who flood the community to earn a living. This has resulted in an increase in the demand for facilities in Amassoma and thereby producing some socio-economic problems to the inhabitants.

Amassoma is located about $40 \mathrm{~km}$ to the South of Yenagoa the state capital with an altitude of $512 \mathrm{~m}$ above sea level. It is bounded to the North by River Nun, West by Otuan and Wilberforce island, East by Toru-Ebeni and the South by Ogobiri. Amassoma has a diameter of about $6 \mathrm{~km}$ East to West and approximately $2 \mathrm{~km}$ North to South. The population is heterogeneous, consisting of the native Ogboins, students, petty traders and businessmen from other parts of the state and country. It also, hosts other institutions of learning which ranges from nursery, primary, junior and senior secondary schools. In a bid to raise the educational standard of the state as well as to delist the state from the list of educationally disadvantaged state, the first civilian Executive Governor of the state, Chief Diepreye S.P. Alamieyeseigha Ph.D. (JP) launched major reforms of the states' educational system which culmunated in the establishment of four tertiary institutions in different parts of the state, namely School of Nursing, Tombia-Ekpetiama, School of Public Health Technology, Otuogidi, Bayelsa state School of Arts and Science, Agudama-Epie and the famous Niger Delta University, Wilberforce island. All these were aimed at increasing the literacy level and tertiary education enrolment status (Fig. 1) of the state where her indigenes seeking for higher education exceeds 85,000 students. Therefore, the establishment of these tertiary institutions was a move in the right direction as it ensures equitable and easy access to higher education to Bayelsans. While these higher education reforms, especially NDU served as a relief to the entire population of Bayelsans, it marked

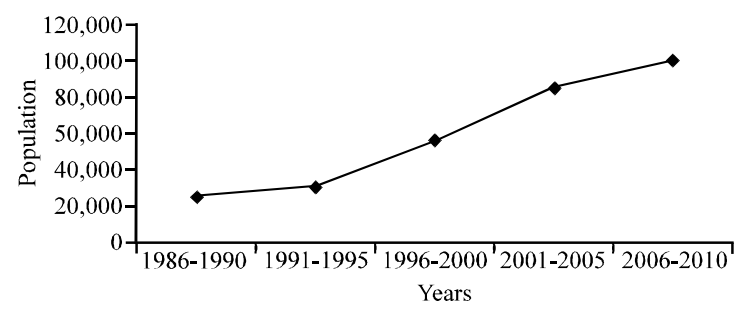

Fig. 1: Population growth in Amassoma; field survey, 2010 
the beginning of urban vices (problems) for the population of Amassoma. However, despite the numerous challenges facing the new state that was created on the 1st of October, 1996 by late General Sani Abacha of blessed memory the then Nigerian Military Head of state, Bayelsa state was faced with acute shortage of human, material and financial resources. Despite these huge challenges, the university still took off with 12 faculties in the 2001/2002 academic session with about 1000 students with 210 academic and 300 supportive staff.

The university was conceived in the British tradition which seeks to foster the unity of the system while situating itself within the larger multilingual and multicultural context of Nigeria because its teaching and research programmes emphasizes relevance, encourages tolerance and promote creative, critical and independent thinking (Ekpang, 2008; Fan et al., 2008).

This study is justified on the premise that the existing literature which empirically assess the socio-economic effects of the establishment of Niger Delta University, Wilberforce island on its environment is non-existent. This probably explains why currently, concrete efforts cannot be proposed by the university and other administrative authorities on issues relating to security, developmental projects as well as the provision of social amenities to the inhabitants of Amassoma. This study is therefore meant to bridge the gap and in this regard, it is structured to provide answers to these questions:

- What are the problems associated with the increasing population of Amassoma community?

- What are the level of demand and supply of housing, land and the effects of these on rent?

- What is the population trend and dynamics within Amassoma and the demand and supply of portable water, electricity, transportation and food?

The objective of the study: The broad objective of this study is to assess the impact of the establishment of the Niger Delta University, Wilberforce island, Bayelsa state on the socio-economic life of Amassoma. The specific objectives are:

- To evaluate the present socio-economic impact of these changes on the population and make projections of potential effects in the future

- To find out the rate of increase in staff population and student enrolment in the university

- To examine the demand and cost of housing and land in Amassoma and its environs
- To assess the trend in the demand for basic social amenities (i.e., portable water, transportation motorcycle, buses and taxis, electricity and recreational facility, etc., in Amassoma

Literature review: A university is the expression of the needs of the community, a society or a nation devoted to the fashioning of the intellect. It is dedicated to the pursuit and propagation of knowledge to the study and clarification of values and to the advancement of the interests of the society and the nation at large. As a product of societal decision, the university acknowledges and advances the claims of the society on it. The claims of the society or the nation on the university are numerous. These include the academic, intellectual, psychological, social, cultural, economic, material, occupational, artistic, physical dimension of a social society as well as the discovery and advancing of these dimensions of the society is a critical function of the university. Therefore, the growth and development of a nation is determined by the extent to which her nonhuman resources are mobilized and utilized by the available human resources to accomplish set goals (Uzurumba et al., 2006; Dasgupta, 2000). Furthermore in most commonwealth countries, there is a close association between housing and town planning which acts in attempt to control over growth of the cities and the planning environment. This is not the situation in Amassoma where there is no respected housing plan. Streets are very few or non-existence. The access to most buildings are difficult and therefore there is congestion which constitute health hazard, since there is total absence of refuse disposal and recreational facilities in such a densely populated area hence the social impact of this to the students and the natives are unimaginable (Ekong, 2003; Luke and Watkins, 2002).

Therefore, the demand for land, modern housing and other basic social amenities cannot be overemphasized as it is a necessity for the university community and it environs even though they attract rent. A recent survey by Ndiyo (2008) and Dasgupta (2000) estimates that about $56 \%$ of the world's urban dwellers are renters. In Amassoma even after the developer has collected enough rents to cover the original amount invested for building the house they still continue to increase the rents at the demerit of tenants thereby putting socio-economic stress on the tenants. Then what is rent? Rent for an apartment is a price for services (i.e., space or facility) that allows the owner to meet his obligations for the mortgage, insurance, tax and maintenance, etc., of a building. Therefore, the cost of construction determines the rent that must be charged if the rental revenues received are to be sufficient 
to indemnify the owner. It is therefore observed that one must give greater attention to the interrelationship between house price, costs and rents because the scarcity of living housing pushes up rental cost to an exorbitant height as exemplified in Abuja the capital of Nigeria (UNCHS, 2001; Dasgupta, 2000). Given the terrain of the community as well as the failure of the indigenes to sell their land to outsiders have led to scarcity of land and where they exist, the price is very high. These have led to exorbitant price hike in the construction of houses. A large population of people living in a small area have put a tremendous pressure on refuse disposal, pipe borne water, electricity, social and recreational facilities. Government regulations on the price of land or government acquisition of land for resale to potential builders/developers in Bayelsa state is non-existent while the indigenes withhold their land and fail to develop them according the trend for the demand for houses in Amassoma.

This not withstanding, Carter (1994) observed that it is self evident that towns grow outward from the centre or nucleus but as they do so, the varied user of land become separated one from the other hence generating a standard pattern. Therefore, concerns over environmental quality must be balanced with housing availability and affordability. If one is bidding for land there is the option of bidding for a greater amount of cheaper land and since, people do not want to be crowded they can chose to live further outward and have more land. Furthermore, the analysis of housing in the community reveals that over $80 \%$ of the houses in the city were built between 1999 and 2006. Housing is therefore a major problem because of dissatisfaction with existing conditions. Housing problems are continuously created due to the population explosion of students and staff alike; therefore industrial change, developmental efficiency, emotional security and social status are likely to influence the housing conditions.

\section{MATERIALS AND METHODS}

Source of data: To collect the primary data, a carefully structured questionnaire was designed and administered by trained and experienced research assistants. The researchers distributed the questionnaire to as many students, business operators, landlords, staff of the university, National Union of Road Transports Workers (NURTW), Amassoma branch and government officials as possible and collected the responses from the respondents through research assistants. The measuring instrument used by the researcher for this study is a 4-point Likert-type questionnaire. The questionnaire was divided into 3 sections. Section A had to do with the respondent's personal information, Section B has 15 items 4-point Likert-type while Section C has 10 questionnaire items to measure the socio-economic impact of the establishment of the Niger Delta University on Amassoma city. The instrument was developed by firstly making a list of phrases and words that are possible indicators of each of the variables involved in the study. Each response was given a degree of scores.

Data analysis: The data for this study was collected between December 1st, 2009 and 31st March, 2010. Data analysis was undertaken using qualitative as well as quantitative techniques. It is expected that a major segment of the information to be collected during the survey will be qualitative and may not be easily quantified. Quantitative techniques will be used to measure ethnographic characteristic of sample. Descriptive statistics (tables, frequencies, percentages, histogram, graphs, standard deviation, means, proportion, etc.) are employed in most analysis in summarizing trends, changes and comparisons across certain characteristics (Ndiyo et al., 2005). In this study, the data collected would be analyzed with relevant statistical tools to test for the socio-economic impact of the establishment of Niger Delta University, Wilberforce island, Bayelsa state. Ndiyo et al. (2005) recommended the use of simple percentage and Chi-square $\left(\chi^{2}\right)$ among others in statistical analysis of descriptive studies although this is not a rigid rule.

\section{RESULTS AND DISCUSSION}

The proportion of students enrolled increased from about 1,000 in 2001 to 3,482 in 2010 and that of academic staff increased from 210-649 while that of supportive (nonacademic) staff increased from 300-3,512 (Junior 3,112 and senior 401) within the same period. Male students have increased from about 500 in 2001 to 1,380 in 2010 while female students went from 700-2,102. But the student hotels on campus have provision for only 360 female students. These figures show that the population of staff from 2001-2010 has increased $>10$-folds while that of students has increased $>3$ times (Table 1). According to Ministry of Local Government and Chieftaincy Affairs, Yenagoa, Southern-Ijaw Local Government Council and the Ogboin-North Rural Development Area, the overall population of Amassoma which was estimated at 25,000 in 1990 is now $>100,000$.

The growth in population of the inhabitant of Amassoma has been phenomenal since, the establishment of NDU as shown in Fig. 1, thus stress available amenities such as housing and other basic necessities 
The Soc. Sci., 7 (2): 246-251, 2012

Table 1: Statistics of registered students from 2001-2010 session in NDU

\begin{tabular}{|c|c|c|c|c|c|c|c|c|c|c|}
\hline \multirow[b]{2}{*}{ Faculty } & \multicolumn{10}{|c|}{ Session } \\
\hline & $01 / 02$ & $02 / 03$ & $03 / 04$ & $04 / 05$ & $05 / 06$ & $06 / 07$ & $07 / 08$ & $08 / 09$ & $09 / 10$ & Total \\
\hline Agricultural Technology & NA & NA & 27 & 38 & 132 & 148 & 122 & 189 & 308 & 964 \\
\hline Arts & NA & NA & 124 & 286 & 254 & 244 & 401 & 316 & 461 & 2086 \\
\hline Education & NA & NA & 279 & 436 & 345 & 244 & 310 & 397 & 510 & 2521 \\
\hline Engineering & NA & NA & 382 & 436 & 294 & 366 & 377 & 473 & 514 & 2842 \\
\hline Law & NA & NA & 181 & 181 & 129 & $* * *$ & *** & 162 & 64 & 717 \\
\hline Management Sciences & NA & NA & 542 & 605 & 292 & 395 & 406 & 409 & 287 & 2936 \\
\hline Medical Laboratory Sciences & $s$ NA & NA & 5 & 35 & 45 & *** & $* * *$ & $* * *$ & 88 & 173 \\
\hline Medicine & NA & NA & 177 & 87 & 117 & *** & *** & 125 & 59 & 565 \\
\hline Nursing & NA & NA & 38 & 52 & 68 & 73 & 61 & 91 & 73 & 456 \\
\hline Pharmacy & NA & NA & 82 & 66 & 78 & 77 & 80 & 108 & 78 & 569 \\
\hline Sciences & NA & NA & 166 & 256 & 305 & 276 & 446 & 474 & 667 & 2590 \\
\hline Social Sciences & NA & NA & 337 & 390 & 251 & 287 & 374 & 362 & 373 & 2374 \\
\hline Total & NA & NA & 2340 & 2868 & 2310 & 2110 & 2577 & 3106 & 3482 & 18793 \\
\hline
\end{tabular}

NA: Not Available; **No admission; Admission office, Niger Delta University, Wilberforce island

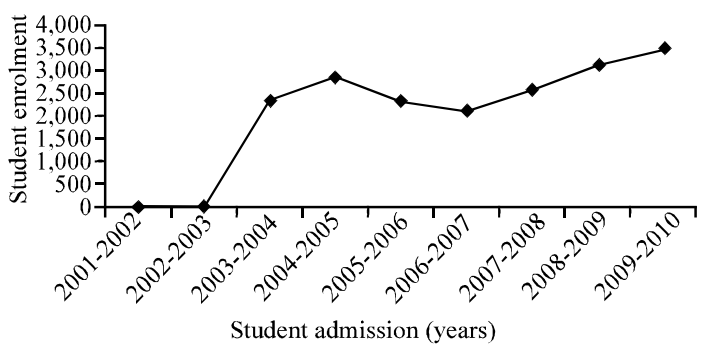

Fig. 2: Trend in registered students; field survey, 2010

as well as an increase in social vices such as rape and armed robbery and other crimes in the area. The annual registered students' enrolment in Niger Delta University (NDU), Wilberforce island, since its inception in 2001 as Table 1 and Fig. 2 reveals an undulating trend while the trend in the 12 faculties' enrolment is represented in a pie chart with their percentage distribution as shown in Fig. 3. Figure 3 indicates that $16 \%$ of the total registered students since 2001 belong to Faculty of Management Sciences. Faculties of Engineering, Sciences, Education/Social Sciences, Arts and Agricultural Technology have 15,14,13, 11 and 5\%, respectively while others have $\leq 4 \%$. This indicates that the admision trend in NDU is proned towards Management Sciences and Engineering based courses.

Cost of land and rents: The analysis of the cost of land for 2001-2009 and related properties as shown in Fig. 1 reveals a growing trend that is increasing in an alarming rate. The cost of a standard plot measuring $15 \mathrm{~m}$ by $30 \mathrm{~m}$ has increased $>20$-fold over this period and this has been accompanied by an equivalent increase in rents within the same period a situation that is causing a of socio-economic stress on both the students and other inhabitants living in Amassoma as shown in Fig. 4 and Table 2. Prior to 2001, the rents for a single room was about 800 month $^{-1}$ but increased to 1,500 in 2001,

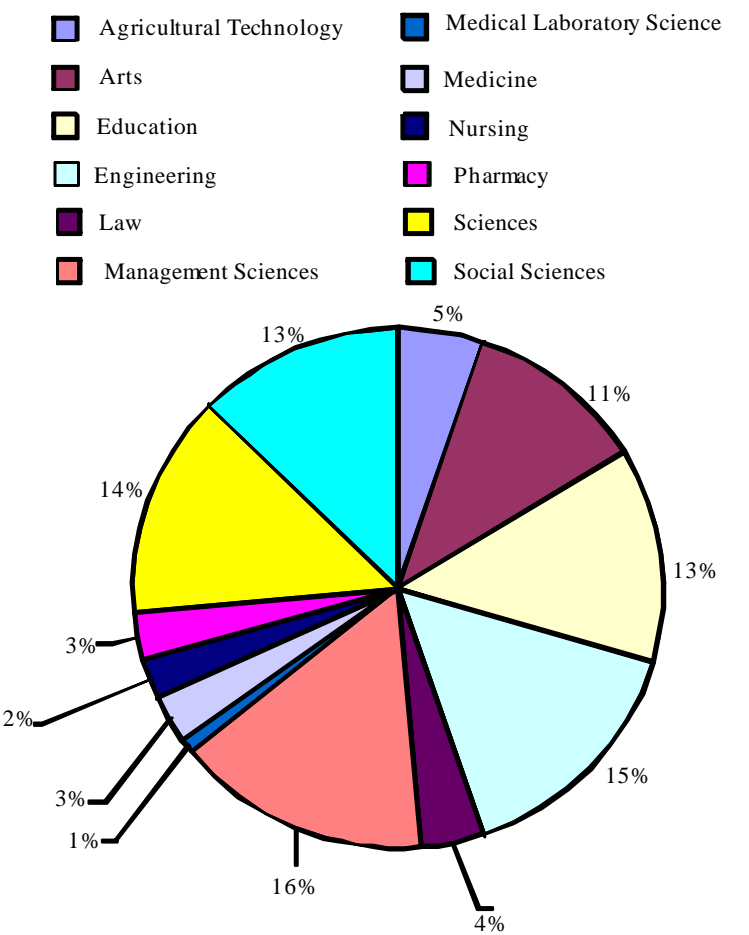

Fig. 3: Faculty student's enrolment trend in NDU; field survey, 2010

2,500 in 2005 and $\$ 3,500$ in 2009. While the variation in rents apartments for self contain, 1,2 and 3 bedroom flats for the same periods are shown in Table 2. Table 2 reveals that the rate of increase in rents in Amassoma and its environs does not depends on costs associated with maintenance, tax payment, etc., as exemplified in the literature review.

The demand for house in Amasoma and it environ: Economic charges always lead to social changes too but the demand for housing is more proportionate to supply of houses. Hence, the demand for houses in Amassoma 
The Soc. Sci., 7 (2): 246-251, 2012

Table 2: Apartment rentage from 2001-2009

\begin{tabular}{|c|c|c|c|c|c|c|c|c|c|c|}
\hline \multirow[b]{2}{*}{ Type of houses } & \multicolumn{10}{|l|}{ Years } \\
\hline & Before 2001 & 2001 & 2002 & 2003 & 2004 & 2005 & 2006 & 2007 & 2008 & 2009 \\
\hline 1 room & 800 & 1,500 & 2,000 & 2,000 & 2,300 & 2,500 & 2,500 & 3,000 & 3,000 & 3,500 \\
\hline 2 room & 1,300 & 1,800 & 2,300 & 2,300 & 3,000 & 3,000 & 3,500 & 3,500 & 3,500 & 4,000 \\
\hline 3 rooms & 1,700 & 2,500 & 2,500 & 2,500 & 3,500 & 3,500 & 4,000 & 4,500 & 4,500 & 5,000 \\
\hline Self contain & 35,000 & 50,000 & 55,000 & 65,000 & 70,000 & 70,000 & 85,000 & 85,000 & 100,000 & 100,000 \\
\hline 1 bedroom flat & NA & NA & 80,000 & 80,000 & 95,000 & 95,000 & 100,000 & 100,000 & 120,000 & 120,000 \\
\hline 2 bedroom flat & NA & NA & 100,000 & 100,000 & 120,000 & 120,000 & 150,000 & 150,000 & 180,000 & 180,000 \\
\hline 3 bedroom flat & NA & NA & 150,000 & 150,000 & 200,000 & 200,000 & 230,000 & 230,000 & 250,000 & 250,000 \\
\hline
\end{tabular}

NA: stand for such houses was Not Available for rent. The rent for self contain and flats are on yearly basis; Fieldwork, 2010

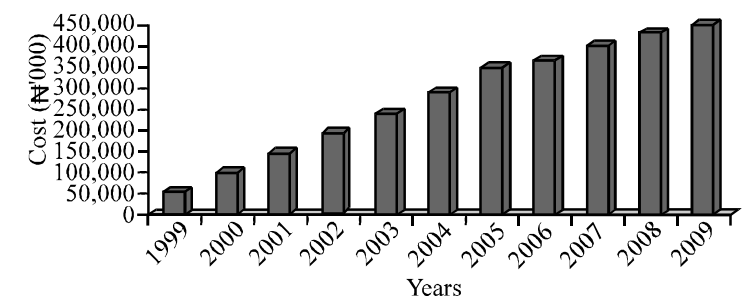

Fig. 4: The histogram of cost of land 2001-2009

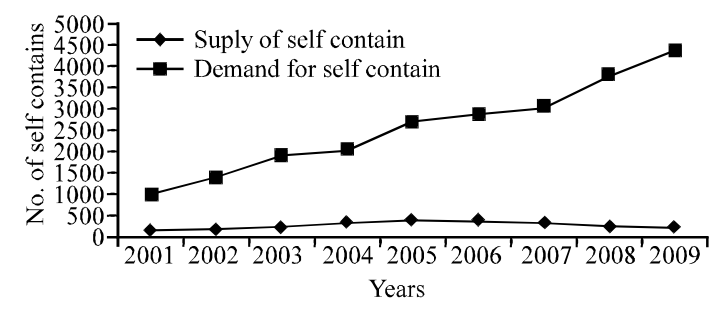

Fig. 5: The graph of supply and demand for self contain from 2001-2009

has been on the increase, since the establishment of the university but the supply of building has not matched this demand as shown in Table 2 and Fig. 5 for trend. Figure 5 reveals that the demand for self contain is far above its supply. This situation exist because the indigenes are not willing to sell their land to would be developer while the government at all levels have fail to acquire and built houses to ameliorate the situation. This has led to an exorbitant increase in house rent in the area. It is therefore projected that to avert this ugly trend, an average of about 4000 self contain year ${ }^{-1}$ need to built in the area for the next 8 years while this should be supported by an average of 2500 rooms year ${ }^{-1}$.

The economic and social impact: Given the above trend, it is believed that the demand for food items will grow rapidly and to get the corresponding supply of food would not be easy. The dominant factor determining food demand in an area has been the population growth. Therefore, the general increase and demand for facilities has equally led to the establishment of markets, hospitals, stores, restaurants, kiosks, bars, cyber cafes, computer centre, hair/barbing saloons, private schools, etc. Also, businesses around the main gate/junction of the university are on the increase as well as food supplies but the prices are exorbitant. There are many eatery and restaurants that provides for breakfast, lunch and dinner. There is also a market and various provision stores at people disposal. World Bank (2008) observed that markets have an influence on the allocation of resources on capital, labour as well as on many microeconomic decisions within the economy.

The study also reveals that there has been an increase in the number of provision stores yet the goods in these stores are very expensive. The main factor responsible for this is population explosion or growth. However in a market driven economy, not only do prices differ from one good to another in such a away that it can been seem illogical but that the price for a single commodity can fluctuate over time. Hence, the shifting of demand/supplies for foods are therefore reflected in price changes and it is price that equates demand with supply. IFAD (2007) opined that prices for food used to very cheap before the start of the liberalization process of the mid 1980's but the case of Amassoma include population explosion. Also in Amassoma, there is no pipe borne water, electricity, good transport system, etc. Audu (2008) observed that high prices and high profit provides market signals for expansion of supply while low prices and low profits provide market signals for contraction of supply which is in consonance with economic theory.

The demand for pipe borne water and electricity is very high in Amassoma but it is non-existence as the inhabitants rely solely on borehole water and personal generator (both on campus and off campus) for survival, therefore this is as a result of government total neglect to its social responsibility to the people. Furthermore, the number of registered buses and taxis from 2001-2009 are as shown in Fig. 6. There has been a steady increase in buses and taxis from Bayelsa state Transport Company (BTC) and the National Union of Road Transports Workers (NURTW) and this is understandable due to the population explosion and the quest to maximise profit. 


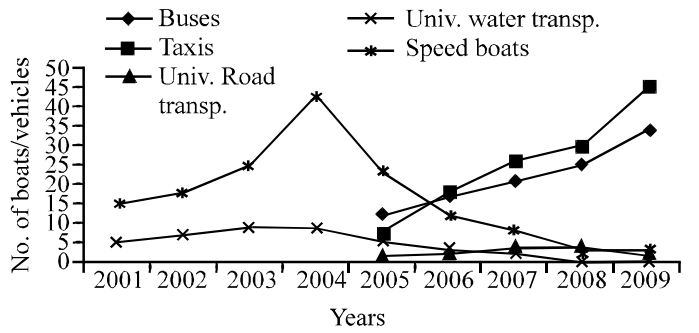

Fig. 6: Trend in registered speedboats, buses and taxis from 2001-2009 field survey, 2010

Prior to May, 2005, Amassoma was only accessible by water, hence the phenomenal increase in speed boats to convey passengers from Yenagoa and other parts of the state to Amasoma but with the emergence of road there was a sharp decline in water transport as exemplified in Fig. 6. The university as its welfare scheme also acquired buses to convey both students and staff to Yenagoa the state capital as shown in Fig. 6. However, the growth in commercial transpiration in the area is as a result of it high viability or profit because of the number of passengers and goods that ply the road on a daily basis. The rapid population growth in Amassoma has led to insecurity with student's occasional harassment by people of the underworld. Despite the intervention of the university authority and government, the harassment has still continued unabated. The trend in these increases will definitely continue to rise as the student enrolment increases and this will lead to greater negative socioeconomic impact on the inhabitants.

\section{CONCLUSION}

A holistic assessment of the extent of the effects of the establishment of Niger delta University Wilberforce island, Bayelsa state in its temporary site at Amassoma in 2001 on the socio-economic life of the inhabitants reveals an increasing trend in the demand and supply of land, housing and other social amenities. The demand for completed apartments far outweigh its supply while there is insufficient or total absence of portable drinking water, electricity, streets, etc., and it is projected that the cost of land will triple in the next few years if not properly checked by government.

\section{RECOMMENDATIONS}

The projection of the various trends into the future will be useful for identifying new areas for further settlement, planned developmental projects as well as the provision of social services such as hospitals, health centres, refuse disposal, security and above all a better control of rents for students who live in off campus. It is hoped that this will reduce the mistake of the past 9 years of the existence of Niger Delta University which has been marred by uncontrollable housing project and the high demand for facilities which constitute negative socioeconomic consequences on the people living in the area and its surrounding environment. These increases have drastically changed the socio-economic life of the natives from a purely rural community to a densely populated cosmopolitan settlement with insecurity, high cost of living as well as total absent of recreational facilities, pipe borne water and electricity for the inhabitants. The latter must be provided if Amassoma is to attain the status of an urban city.

\section{REFERENCES}

Audu, N.P., 2008. Globalization and Nigeria's agricultural exports. Ikogho, 4: 74-78.

Carter, H., 1994. Urban and Rural Settlement. Longman Publishers, Singapore.

Dasgupta, P., 2000. Population and resources: An exploration of reproductive and environmental externalities. Populat. Dev. Rev., 26: 643-689.

Ekong, E.E., 2003. An Introduction to Rural Sociology. Dove Educational Publishers, Uyo, Nigeria..

Ekpang, M.A., 2008. The university as an instrument of national development and intergrety: A critical perspective. Int. Res., 1: 33-35.

Fan, F.A., J.E. Egomo, O. Ochagu, U.E. Eloma and S.D. Edinyang, 2008. Education for quality environment: A necessity for all Nigerian students. Int. Res., 1: 112-120.

IFAD, 2007. Beyond Export-Led Growth: The Challenges of Agricultural Exports in Nigeria. Oxford University Press, Oxford, UK., pp: 7-22.

Luke, N. and S.C. Watkins, 2002. Reaction to developing-country elites to internal population policy. Population Dev. Rev., 28: 707-733.

Ndiyo, N., G. Akankpo and C. Ofuka, 2005. Secondary education strategy and national development in Nigeria: The case of Cross River State. Niger. J. Econ. Dev. Matters, 4: 86-114.

Ndiyo, N.A., 2008. Poverty to Sustainable Development: A Communist-Based Approach. University of Calabar Press, Calabar, Nigeria.

UNCHS, 2001. Cities in a Globalizing World: Global Report on Human Settlements. Earthscan Publication, London, UK., Pages: 344.

Uzurumba, E., A. Udidia and J. Ebuara, 2006. University as an effective instrument for national development and unity in Nigeria. In A.J. Isangedighi ed. Education for Today. J. Fac. Educ. Univ. Calabar, Vol. 6.

World Bank, 2008. Improving marketing system in developing countries: An approach to identifying problems and strengthening technical support. Foreign Agricultural Economic Report, Geneva, Switzerland. 